\title{
Vibroacoustic diagnosis of EGR system
}

\begin{abstract}
The Exhaust Gas Recirculation is a popular system of recirculation of the automotive vehicle emission. The principle of working depends on the forcing in the part of outlet gas to the combustion chamber. The polluted flowing valve of circuit has an influence on stability of engine's work. The authors presents a new way of diagnosis in automotive vehicle which depend on detection and measure of vibroacustic vibrations that were subjected to digital signal processing. It seems that EGR circuit that does not work properly shouldn't have an influence on vibrations generated by an engine. However, authors indicate that this statement is wrong.
\end{abstract}

Key words: DSP, EGR, vibroacoustic, automotive diagnosis

\section{Diagnostyka wibrometryczna ukladu EGR}

System recyrkulacji spalin gazów wylotowych jest popularnym systemem wykorzystywanym do ograniczania emisyjności pojazdów samochodowych. Zasada działania systemu jest oparta na wtłoczeniu do komory spalania części gazów wylotowych. Zanieczyszczony zawór dolotowy systemu ma wpływ na stabilna pracę silnika. W niniejszym artykule autorzy prezentuja nowa metodykę diagnostyczna oparta na pomiarze drgań, poddanych operacjom cyfrowego przetwarzania sygnału. Wydaje się, że nieprawidłowo działajacy układ EGR nie powinien mieć wpływu na drgania generowane przez silnik. Autorzy wykazuja, że takie stwierdzenie jest btędne.

Słowa kluczowe: DSP, recyrkulacja spalin, wibroakustyka, diagnostyka samochodowa

\section{Introduction}

Since the 1960s, when rapid degeneration of the environment was first noticed, ways of reducing the emission of dangerous substances by automotive vehicles have been sought. The dangerous compounds are hydrocarbons (HC), nitrogen oxides $\left(\mathrm{NO}_{\mathrm{x}}\right)$ and carbon dioxide $\left(\mathrm{CO}_{2}\right)$. The dangerous emissions can be reduced by [1]:

a) Improving the fuel.

b) Improving lubrication.

c) Maintaining higher thermal stability.

d) Perfectly insulating the system.

e) Using catalytic systems.

Among the systems which have a bearing on engine thermal economics by reducing lean mixture temperature there is the Exhaust Gas Recirculation (EGR) system whose principle of operation consists in forcing some of the exhaust gas back into the combustion chamber [2].

The first experiences with EGR systems date back to the 1970s. The operation of the system was then limited to steady feeding the exhaust gas to the combustion chamber when the vehicle user turned on the system by means of a proper switch. That system only partially fulfilled its functions which included [3]:

a)Lowering the combustion temperature of the lean mixture. b) Oxidizing harmful substances.

c) Accelerating fuel vaporization.

As one can easily guess, the first vehicles with the EGR, which, thanks to General Motors, appeared on the American market in 1973 contributed little to emission reduction. It was mainly the fault of the human being who would decide when the EGR was and was not to work. In the late 1970s the system was improved by introducing a primitive diagnostic
1. Wstęp

Od lat sześćdziesiątych XX w., kiedy zauważono szybką degenerację środowiska, poszukuje się sposobów na ograniczenie emisji substancji szkodliwych przez pojazdy samochodowe. Tymi niebezpiecznymi związkami są węglowodory $(\mathrm{HC})$, tlenki azotu $\left(\mathrm{NO}_{\mathrm{x}}\right)$ oraz dwutlenek węgla $\left(\mathrm{CO}_{2}\right)$. Zmniejszenie niebezpiecznej emisyjności można osiągnąć przez [1]:

a) doskonalenie paliwa,

b)doskonalenie smarowania,

c) utrzymanie większej stabilności termicznej,

d)wykonanie doskonałej izolacji układu,

e)użycie układów katalitycznych.

Wśród układów, które wpływają na gospodarkę termiczną silnika przez obniżenie temperatury ubogiej mieszanki jest układ EGR (ang. Exhaust Gas Recirculation), którego zasada działania polega na wtłoczeniu do komory spalania części gazów wylotowych [2].

Pierwsze doświadczenia z systemem EGR sięgają lat 70. ubiegłego stulecia. Praca systemu była ograniczona do stałego doprowadzania gazów wylotowych do komory spalania, o ile użytkownik pojazdu włączył system za pomocą właściwego włącznika. Taki system tylko połowicznie spełniał swoje zadania, do których należą [3]:

a)obniżenie temperatury spalania ubogiej mieszanki,

b)utlenienie substancji szkodliwych, pozostałych po ostatnim cyklu,

c)przyspieszenie odparowywania paliwa.

Pierwsze pojazdy z zaimplementowanym systemem EGR, które weszły na rynek amerykański dzięki koncernowi General Motors w 1973 r. miały bardzo mały wpływ na ograniczenie emisyjności. Głównym powodem tego był człowiek, który 
system whose integral part was a temperature sensor located on the cooler. It would turn on the EGR (provided the decision unit, i.e. the human being, had switched on the whole system) only at specified engine (coolant) temperatures. The next generations of the system were equipped with timing circuits which would switch off the EGR for a few seconds after the throttle was fully opened.

In 1983 research on the 4th generation EGR which is human-independent, i.e. it takes its own decisions about switching the system on or off, started. Besides taking the right switching decision, the system also decides what percentage of the exhaust gas can be turned back to the combustion chamber. The modern EGR takes a decision to switch on the system only if the following conditions are fulfilled [3]:

a) The engine temperature is higher than $77^{\circ} \mathrm{C}$.

b) The temperature under the bonnet is above $-6^{\circ} \mathrm{C}$.

c) The engine has been working for at least 3 minutes at the above temperatures.

d)The crankshaft rotational speed is 1952-2400 rpm for the manual gearbox.

e) The crankshaft rotational speed is $2248-2688 \mathrm{rpm}$ for the automatic gearbox.

f) The exhaust gas overpressure is $667-2667 \mathrm{~Pa}$.

$\mathrm{g})$ The fuel temperature does not differ from the one specified by the vehicle manufacturer $\left(\mathrm{T}_{\mathrm{o}}\right)$ by $-8 \%$ to $+7 \%$.

h) The voltage generated by the throttle opening sensor is in a range of $0.6-1.8 \mathrm{~V}$.

i) The driving speed is higher than $40 \mathrm{~km} / \mathrm{h}$.

\section{Development of EGR}

EGR systems are highly complex, particularly as regards their electronics and sensor system. However, when one examines the evolution of the EGR one can notice similarities to other emission reducing system. This is illustrated in Fig. 1.

The emission reduction idea led to the development of the 1st generation EGR which is a simple implementation of this idea. Its control is limited to switching the system on by the human being at a proper moment, similarly as in other systems, e.g. in the 1st generation LPG system. The 2nd generation systems are equipped with a temperature sensor to aid the human being in decision taking.

The systems installed in cars have evolved in two ways, depending on system complexity and popularity. If the system is simple and there is a demand for it, a hybrid is usually created by adding a processor diagnostic system which eliminates the human being from decision taking. The diagnostic system takes decisions on the basis of oneor two-dimensional information coming from sensors (e.g. temperature and crank sensors). This is the case in LPG systems. The EGR has evolved in the other way, i.e. the decision still belongs to the human being who can switch the system off, but he/she is aided by systems consisting of many sensors (the 3 rd generation system).

The synthesis is the 4th generation system. Here the human being does not take any decisions. Everything proceeds automatically, but so as not to disturb the operation of the engine or adversely affect driving safety and ergonomics. sam podejmował decyzję, kiedy EGR ma działać, a kiedy nie. Dopiero druga połowa lat 70. XX w. przyniosła udoskonalenie systemu polegające na dodaniu prymitywnego systemu diagnostycznego, którego integralną częścią był czujnik temperatury umieszczony na chłodnicy. Umożliwiał on włączenie układu EGR (oczywiście, o ile jednostka decyzyjna, czyli człowiek, wcześniej włączyła cały system przy użyciu właściwego przycisku) tylko w ustalonych temperaturach silnika (płynu chłodzącego). Następne generacje systemu zostały wzbogacone o układy czasowe, które wyłączały układ EGR na kilka sekund po całkowitym otwarciu przepustnicy.

Od roku 1983 zaczęto prowadzić pracę nad systemem EGR „IV generacji”, który jest niezależny od człowieka, sam podejmuje decyzje o załączeniu lub odłączeniu układu. Oprócz właściwej decyzji system decyduje także o tym, w ilu procentach gazy wylotowe mogą znaleźć się z powrotem w komorze spalania. Współczesny układ EGR podejmie decyzję o możliwości załączenia układu, tylko po spełnieniu poniższych warunków [3]:

a)temperatura silnika musi być wyższa niż $77^{\circ} \mathrm{C}$,

b)temperatura w komorze silnika musi być wyższa niż $-6^{\circ} \mathrm{C}$,

c) silnik pracował minimum 3 minuty przy wyżej wymienionych temperaturach,

d)prędkość obrotowa wału korbowego wynosi 1952-2400 obr/min przy manualnej skrzyni biegów,

e)prędkość obrotowa wału korbowego wynosi 2248-2688 obr/min przy automatycznej skrzyni biegów,

f) nadciśnienie spalin wynosi 667-2667 Pa,

g)temperatura paliwa nie różni się od wartości ustalonej przez producenta pojazdu o wartość od $-8 \%$ do $+7 \%$,

h)napięcie generowane przez czujnik otwarcia przepustnicy zawiera się w granicach $0,6-0,8 \mathrm{~V}$,

i) prędkość pojazdu jest większa niż $40 \mathrm{~km} / \mathrm{h}$.

\section{Rozwój systemu EGR}

System EGR cechuje się dużą złożonością i znacznym skomplikowaniem układu, szczególnie w odniesieniu do elektroniki i zespołu czujników, które są jego integralną częścią. Jednocześnie, analizując opisaną drogę rozwoju systemu EGR, należy zauważyć podobieństwo do innych układów służących ograniczeniu emisyjności. Kolejne generacje systemu EGR przedstawiono na rys. 1.

Pomysł ograniczenia emisyjności doprowadził do opracowania układu EGR, tzw. „I generacji”. Układ taki jest prosty i jest bezpośrednią implementacją pomysłu. Jego sterowanie ogranicza się do włączenia systemu przez człowieka w odpowiednim momencie, podobnie jak ma to miejsce w innych systemach, np. instalacji gazu LPG I generacji. Układy „II generacji” charakteryzują się dodaniem czujnika temperatury, mającego pomóc człowiekowi w „procesie decyzyjnym”.

Rozwój systemów instalowanych na pokładzie samochodu cechuje pewna dwutorowość, zależna od stopnia skomplikowania i popularności systemu. Jeżeli system jest prosty, a jednocześnie rynek wymusza zapotrzebowanie na niego, powstaje hybryda, która zamyka człowiekowi możliwość decyzji przez dodanie procesorowego układu diagnostycz- 


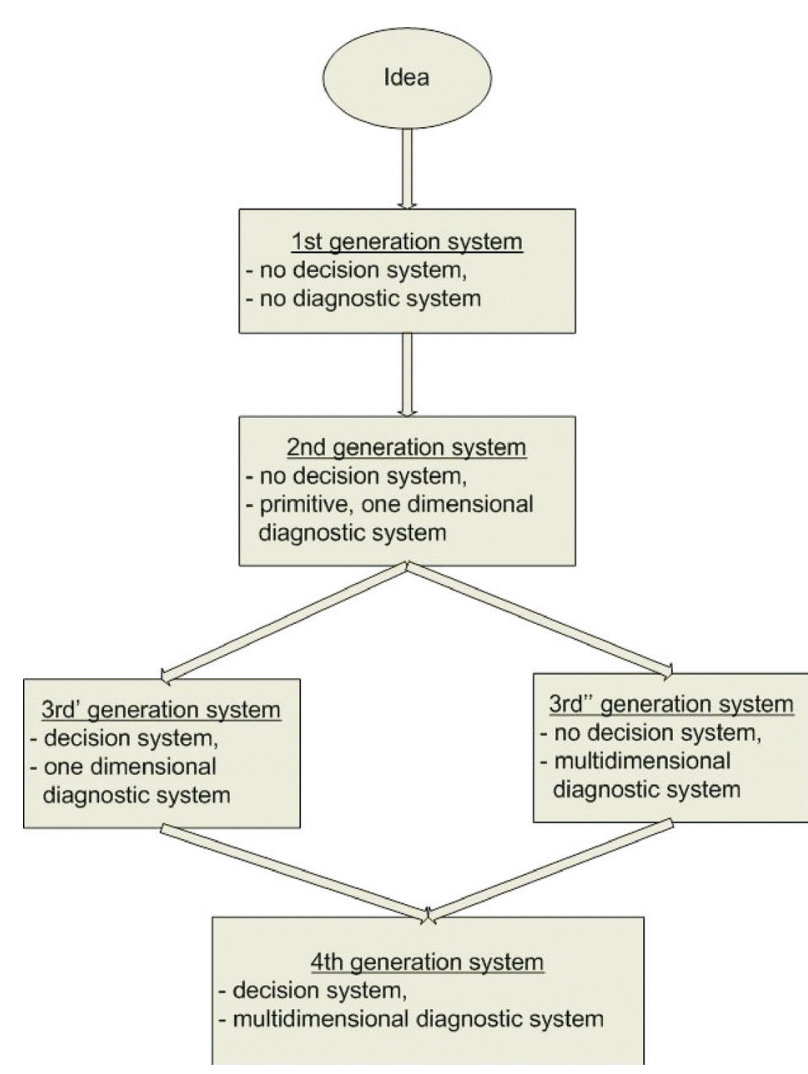

Fig. 1. Evolution of emission reducing systems Rys. 1. Ewolucja systemów ograniczajacych emisyjność

\section{Operation of EGR}

Although the idea seems to be simple, since it consists in pumping some of the exhaust gas back to the combustion chamber, its implementation is not so obvious. Two groups of systems [5] are distinguished:

a) Pneumatically controlled.

b) Electronically (processor) controlled.

As a rule, the operation of electronically controlled systems is based on a decision unit in the form of a (micro-) processor system. The decision whether to switch the system on and about the amount of exhaust gas which is to be forced back into the combustion chamber belongs solely to the integrated circuit which takes the decision on the basis of the information coming from the sensor CAN bus.

The EGR, belonging to the group of negative pressurecontrolled sensors [2], is employed in both supercharged and unsupercharged engines. Generally speaking, in all the EGR systems known so far the valve is opened by a negativepressure servomotor and closed by an elastic element [5]. Subpressure is produced by a double-purpose pump called a tandem pump, which is a combination of a fuel pump and a subpressure pump in one housing (Fig. 2). The subpressure value is adjusted by an electrovalve (Fig. 3) controlled by the information contained in the rectangular signal. In this case, this is pulse-duty factor $\mathrm{k}_{\mathrm{w}}$ (Fig. 4):

$$
\mathrm{k}_{\mathrm{w}}=\frac{\mathrm{t}_{\mathrm{i}}}{\mathrm{T}}
$$

where: $t_{i}-$ pulse duration, $\mathrm{T}-$ the period. nego. Podejmuje on decyzję na podstawie jedno- lub dwuwymiarowych informacji pochodzących od czujników (np. temperatury i prędkości obrotowej wału korbowego). Ten przypadek dotyczy właśnie instalacji gazowych. Ewolucja układu EGR poszła „drugim torem”: decyzja ciągle należy do człowieka, który może układ odłączyć, ale pomagają mu układy wielu czujników - układ „III generacji”.

Syntezą jest układ „IV generacji”, w którym człowiek nie podejmuje żadnej decyzji. Wszystko przebiega automatycznie, jednak w taki sposób, żeby nie zakłócić pracy silnika i nie wpływać na bezpieczeństwo i ergonomię jazdy.

\section{Dzialanie układu EGR}

O ile sam pomysł wydaje się prosty, ponieważ polega na wtłoczeniu części gazów wylotowych do komory spalania, to jego implementacja nie jest już tak oczywista. Wyróżnia się dwie grupy układów [5]:

a) sterowane pneumatycznie,

b) sterowane elektronicznie (procesorowo).

Działanie układów sterowanych elektroniczne z zasady opiera się na jednostce decyzyjnej w postaci układu (mikro-) procesorowego. Decyzja o załączeniu układu i ilości gazów, które mają być ponownie wtłoczone do komory spalania zależy tylko od układu scalonego, który podejmuje decyzję W oparciu o informacje pochodzące z magistrali czujników - CAN.

Układ EGR, należący do grupy układów sterowanych podciśnieniem [2], jest wykorzystywany zarówno w silnikach doładowanych, jak i wolnossących. Ogólnie wszystkie znane dotychczas systemy opierają się na otwieraniu zaworu EGR siłownikiem podciśnieniowym, a zamykaniu przy użyciu elementu sprężystego [5]. Metodą uzyskiwania podciśnienia jest użycie pompy „,podwójnego zastosowania”, zwanej ,pompą tandemową". Jest to połączenie pompy paliwa i pompy podciśnienia w jednej obudowie (rys. 2). Wartość podciśnienia jest regulowana elektrozaworem (rys. 3), który jest sterowany informacją zamieszczoną w sygnale prostokątnym w postaci wartości współczynnika wypełnienia impulsu $\mathrm{k}_{\mathrm{w}}(1)$, gdzie: $\mathrm{t}_{\mathrm{i}}$ - czas trwania stanu wysokiego impulsu sterującego, $\mathrm{T}$ - okres, co przedstawiono na rys. 4.

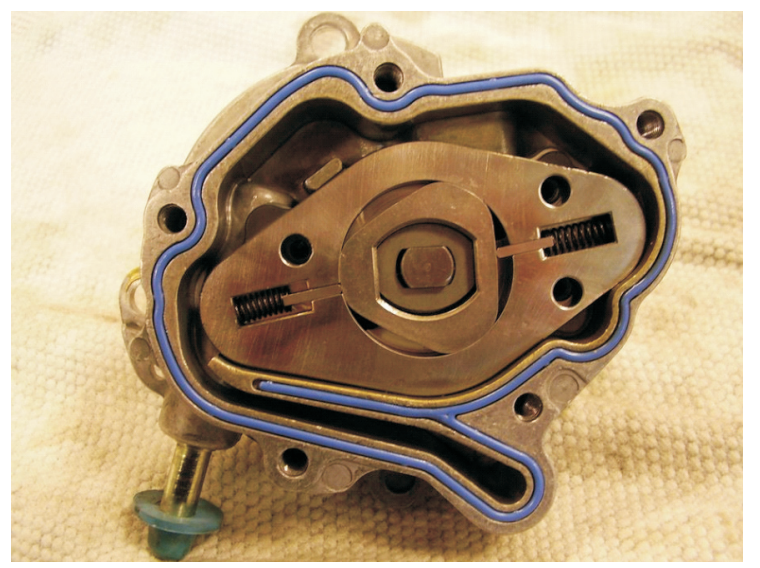

Fig. 2. Negative-pressure pump (fuel pump is on other side) Rys. 2. Pompa podciśnienia (z drugiej strony systemu EGR pompa paliwa) 


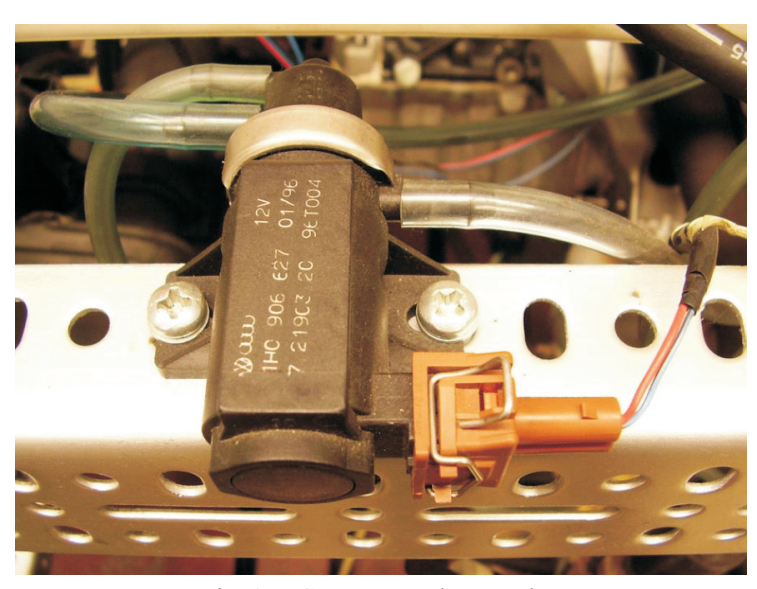

Fig. 3. EGR system electrovalve Rys. 3. Elektrozawór

When the pulse-duty factor is close to 0 , the electrovalve is closed. The degree of valve opening is directly proportional to the value of the factor and the maximum opening is reached at $\mathrm{k}_{\mathrm{w}}=1$.

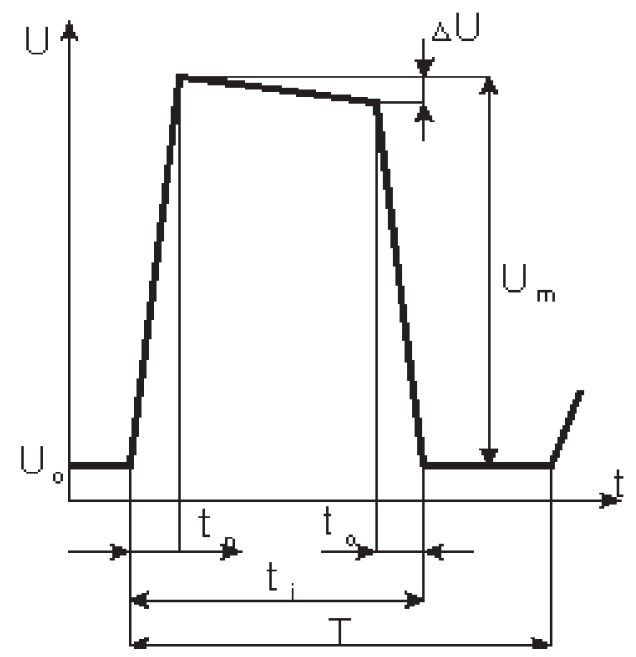

Fig. 4. Ideal pulse

Rys. 4. Schemat impulsu idealnego

The control system allows switching on the ERG only in certain engine operating conditions (described in chapter 1). But never the entire exhaust gas is forced back into the combustion chamber. The amount of exhaust gas which is forced in depends on [5]:

a) The mass of the air sucked in by the engine.

b) The volume of the air sucked in by the engine.

c) The throttle opening angle.

d) The absolute pressure in the intake manifold.

e) The exhaust gas overpressure in the exhaust system.

\section{EGR failures}

In the literature on the subject and also on Internet forums the EGR and the need for its existence are often discussed. Unfortunately, many users who know how the EGR system works switch it off to improve the performance of their vehicles and prevent failures in the intake systems [4]. As a result, the EGR valve in the supercharged engine gets gummed up,
Gdy współczynnik wypełnienia jest zbliżony do wartości 0 - elektrozawór jest zamknięty. Stopień otwarcia zaworu jest wprost proporcjonalny do wartości współczynnika i osiąga maksymalne otwarcie dla $\mathrm{k}_{\mathrm{w}}=1$.

Układ sterujący zezwoli na załączenie układu EGR tylko w pewnych warunkach pracy silnika, opisanych w rozdz. 1 . Nigdy jednak nie dojdzie do sytuacji, w której całość gazów wylotowych będzie wtłoczona do komory spalania. Ilość wtłaczanych gazów wylotowych jest uzależniona od [5]:

a) masy powietrza zassanego przez silnik,

b) objętości powietrza zassanego przez silnik,

c) stopnia otwarcia przepustnicy,

d) ciśnienia bezwzględnego w kolektorze dolotowym,

e) nadciśnienia spalin w układzie wylotowym.

\section{Uszkodzenia układu EGR}

W literaturze, a także w dyskusjach internetowych często pojawia się temat dotyczący EGR i potrzeby jego istnienia. Niestety, wielu użytkowników znających zasadę działania układu - wyłącza go, aby poprawić osiągi pojazdów i zapobiec uszkodzeniom w układach dolotowych [4]. Działanie to prowadzi do zanieczyszczenia zaworu układu EGR w silniku doładowanym (rys. 5). To właśnie gromadzenie się nagarów może spowodować całkowite zablokowanie elektrozaworu EGR, które może być z kolei powodem uszkodzenia sondy lambda i prowadzić do niebezpiecznych konsekwencji.

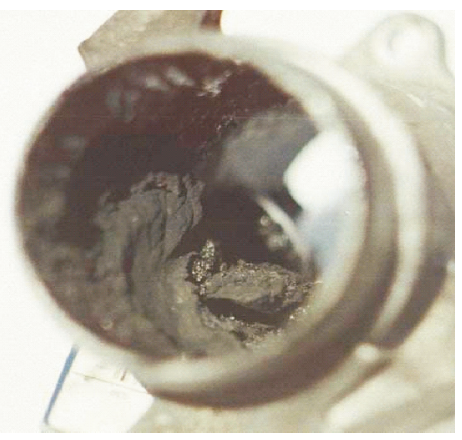

Fig. 5. Gummed up intake valve of EGR [4]

Rys. 5. Zanieczyszczony zawór dolotowy układu EGR [4]

Zawór EGR może być zablokowany także wtedy, gdy układ podciśnienia będzie nieszczelny lub będzie uszkodzony układ sterowania szerokością impulsu. Nieszczelność układu podciśnienia jest typowym uszkodzeniem tak sterowanych układów. Problemem są tutaj znajdujące się w pobliżu gorących części silnika przewody doprowadzające podciśnienie do układu EGR. Uszkodzenie przewodu doprowadzającego podciśnienie prowadzi, między innymi, do gaśnięcia silnika, zarówno przy nienagrzanym, jak i gorącym silniku.

Oprócz wyżej wymienionych uszkodzeń może nastąpić uszkodzenie układów czujników, które „pomagają” jednostce procesorowej w podjęciu decyzji o załączeniu układu EGR. Do tych czujników należą między innymi [6]:

a)czujnik pomiaru temperatury płynu chłodniczego CTS (ang. Coolant Temperature Sensor). Układ ten to termistor NTC (ang. negative temperature coefficient). Typowe wartości rezystancji tego czujnika zawiera tab. 1; 
as shown in Fig. 5. Carbon deposit accumulation may totally block the EGR electrovalve and thereby damage the lambda probe, which leads to serious consequences.

The EGR valve can also be blocked when the negativepressure system is untight or the pulse length control system is damaged. Negative-pressure system leakage is a typical failure of systems controlled in this way. The problem here is that the pipes feeding negative pressure to the EGR system are located close to the hot engine parts. Damage to a negative pressure feeding pipe results in, among other things, engine stalling both when the engine is cold and hot.

Besides the failures mentioned above, the systems of sensors which aid the processor unit in taking the ERG system switch on decision may fail. The sensors include [6]:

a) A coolant temperature sensor (CTS), which is an NTC (Negative Temperature Coefficient) thermistor. The typical resistances of this sensor are shown in the table below (Tab. 1).

b)A throttle position sensor (TPS), which is a potentiometer measuring voltage drop.

c) An oxygen sensor (OS), which is located in the throttle system and measures air volume. It usually works in tandem with a rate generator coupled with an A/D converter.

d)An intake air temperature (IAT) sensor, which, similarly as the coolant temperature sensor, an NTC thermistor. As opposed to the thermistor which measures coolant temperature, a semiconductor thermistor with a different dopant is used in this case. This affects the resistance values versus temperature (Tab. 2).

Table 2. Resistance values versus intake air temperature sensor temperature

Tabela 2. Wartości rezystancji w funkcji temperatury powietrza w uktadzie dolotowym

\begin{tabular}{|c|c|c|}
\hline No. & $\mathrm{R}[\Omega]$ & $\mathrm{t}\left[{ }^{\circ} \mathrm{C}\right]$ \\
\hline 1 & 185 & 99 \\
\hline 2 & 450 & 70 \\
\hline 3 & 1800 & 40 \\
\hline 4 & 3400 & 20 \\
\hline 5 & 7500 & 0 \\
\hline 6 & 25000 & -20 \\
\hline 7 & 100700 & -40 \\
\hline
\end{tabular}

e)A crank sensor (CS).

f) A manifold absolute pressure (MAP) sensor.

A failure of any of the systems mentioned above will cause a malfunction of the EGR system.

EGR faults have special a special symbol in the EOBD (OBD II) code, i.e. the value 4 in the 3 rd field of the fault code [5].

A new method of diagnosing the EGR system, based on the multidimensional function of compression-ignition engine vibration, is presented below.

\section{Measurement methodology}

Since 2008 the CAN bus can be the only diagnostic medium in automotive vehicles. Furthermore, since 2001 each
Table 1. Resistance values against coolant temperature sensor temperature

Tabela 1. Wartości rezystancji w funkcji temperatury czujnika temperatury chłodnicy

\begin{tabular}{|c|c|c|}
\hline No. & $\mathrm{R}[\Omega]$ & $\mathrm{t}\left[{ }^{\circ} \mathrm{C}\right]$ \\
\hline 1 & 177 & 99 \\
\hline 2 & 467 & 70 \\
\hline 3 & 1459 & 40 \\
\hline 4 & 3520 & 20 \\
\hline 5 & 9420 & 0 \\
\hline 6 & 28680 & -20 \\
\hline 7 & 100700 & -40 \\
\hline
\end{tabular}

b)czujnik otwarcia przepustnicy TPS (ang. Throttle Position Sensor). Jest to potencjometr, na którym mierzona jest wartość spadku napięcia;

c)czujnik ilości powietrza $\mathrm{O}_{2}$ (ang. Oxygen Sensor). Czujnik umiejscowiony w układzie przepustnicy, mierzący objętość powietrza. Jest on wykonywany najczęściej w układzie prądnicy tachometrycznej, sprzężonej z układem przetwornika analogowo-cyfrowego;

d)czujnik temperatury powietrza w układzie dolotowym IAT (ang. Intake Air Temperature/Mass Air Temperature (MAT Sensor)). Podobnie jak w czujniku temperatury - jest to termistor NTC. W porównaniu do termistora mierzącego temperaturę płynu chłodniczego, w tym przypadku stosowany jest termistor półprzewodnikowy o innym domieszkowaniu, co wpływa na wartości rezystancji w funkcji temperatury (tab. 2);

e)czujnik prędkości obrotowej wału korbowego CS (ang. Crank Sensor);

f) czujnik wartości ciśnienia ładowania MAP (ang. Manifold Absolute Pressure Sensor).

Uszkodzenie każdego z wyżej wymienionych układów spowoduje nieprawidłowe działanie układu EGR. Uszkodzenia układu recyrkulacji spalin mają własne specjalne oznaczenia w systemie EOBD (OBD II). Mowa tutaj o 3. polu kodu usterki, który w przypadku uszkodzenia układu EGR będzie zawierał wartość „4” [5].

Autorzy niniejszego artykułu zaprezentują nową metodę diagnostyki układu EGR, opartą na funkcji drgań silnika o zapłonie samoczynnym.

\section{Metodyka pomiaru}

Od roku 2008 jedynym medium diagnostycznym w pojeździe samochodowym ma być magistrala CAN. Od roku 2001 każdy nowy europejski pojazd jest wyposażony w układ diagnostyki pokładowej EOBD. System ten umożliwia bieżącą diagnostykę 849 uszkodzeń [7]. Diagnostyka polega na pojawieniu się tzw. ramki dominującej standardu CAN z informacją o uszkodzeniu, a oparta jest na grupie czujników, które sprawdzają czy otrzymywane wartości (pochodzące $\mathrm{z}$ różnych układów) mieszczą się w odpowiednich przedziałach. Wszystkie stosowane obecnie sensory muszą być umieszczone w pobliżu mierzonej wartości.

Prezentowana nowatorska metodyka diagnostyki układu EGR nie wymaga bezpośredniego dostępu do badanej 
new European vehicle has been equipped with the European On Board Diagnostics (EOBD) system which enables the real-time diagnosis of 849 faults [7].

The presented here EGR diagnostics methodology does not require direct access. The proposed system diagnoses many faults through a dedicated analysis of combustion engine vibrations. It would seem that the exhaust gas recirculation system has no effect on the (vibroacoustic) vibrations generated by the engine. However, it turns out that such diagnostics is possible.

Figure 6 shows a measuring rig which includes an engine (1), an electrorotary brake (2) and a vibrometeric head (3) which records vibrations.

\subsection{Tested object: compression- ignition engine}

A compression-ignition Volkswagen, 1.9TDi engine was used for the tests. The engine is with direct injection effected by a system of injection units, a turbocharging system with adjustable charger guide blades and a turbocharging air cooling system, and an intercooler.

The engine performance specifications are as follows:

a) Maximum power - $74 \mathrm{~kW}(101 \mathrm{KM})$ at $4000 \mathrm{rpm}$.

b)Maximum torque $-250 \mathrm{~N} \cdot \mathrm{m}$ at 1900 rpm.

Figure 7 shows the external performance of the tested engine. powierzchni, generującej drgania. Proponowany system pozwala na badanie wielu usterek przez dedykowaną analizę drgań silnika spalinowego. Mogłoby się wydawać, że system recyrkulacji spalin nie ma wpływu na drgania (zwane często wibroakustycznymi) generowane przez silnik. Jednak okazuje się, że taka diagnostyka jest możliwa.

$\mathrm{Na}$ rysunku 6 przedstawiono stanowisko pomiarowe $\mathrm{z}$ silnikiem (1), hamulcem elektrowirowym (2) oraz głowicą wibrometryczną (3) rejestrującą drgania.

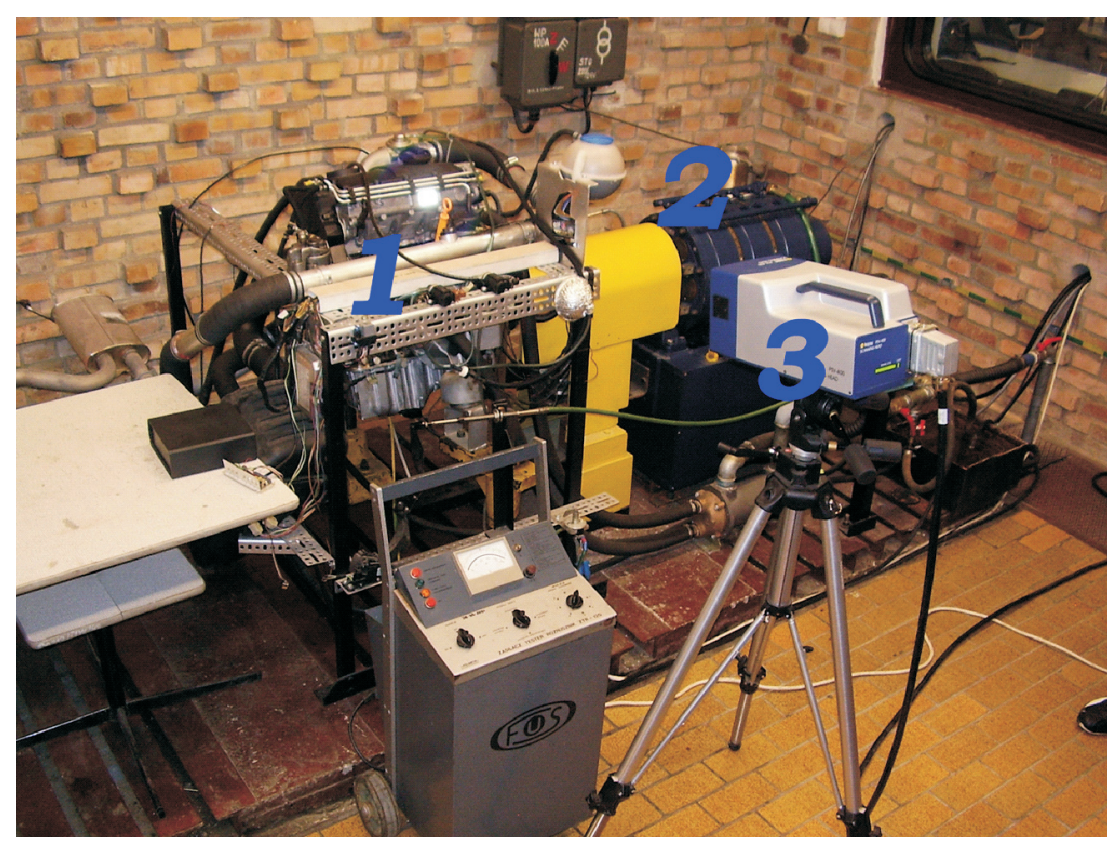

Fig. 6. Measuring rig: engine (1), electrorotary brake (2), vibrometeric head (3) Rys. 6. Stanowisko pomiarowe; silnik (1), hamulec (2), głowica wibrometryczna (3)

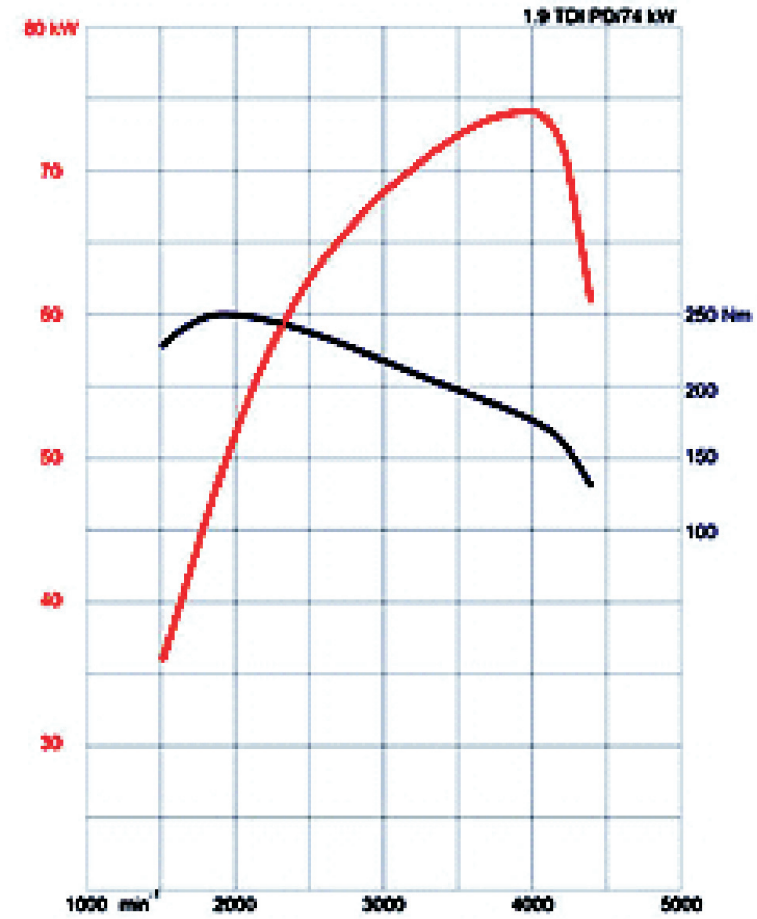

Fig. 7. Tested engine performance [14]

Rys. 7. Charakterystyka silnika użytego w badaniach [14]

\subsection{Obiekt badań; silnik o zapłonie samoczynnym}

Do badań użyto silnika o zapłonie samoczynnym firmy Volkswagen - 1,9 TDi. Silnik posiada wtrysk bezpośredni, realizowany przez układ pompowtryskiwaczy, system turbodoładowania o zmiennym ustawieniu łopatek kierownicy sprężarki, wyposażony w układ chłodzenia powietrza doładowującego - intercooler.

Silnik charakteryzuje się następującymi osiągami: - moc maksymalna 74 kW (101 KM) dla 4000 obr/min, - maksymalny moment obrotowy $250 \mathrm{~N} \cdot \mathrm{m}$ dla $1900 \mathrm{obr} / \mathrm{min}$.

Na rysunku 7 przedstawiono charakterystykę zewnętrzną silnika użytego do badań.

\subsection{Hamulec stanowiskowy}

Stanowisko hamowniane zaopatrzone było w hamulec elektrowirowy firmy AVL [8], model Ralpha 240. Charakteryzują go następujące parametry [9]:

- moc maksymalna $240 \mathrm{~kW}$,

- maksymalny moment obrotowy $600 \mathrm{~N} \cdot \mathrm{m}$,

- prędkość maksymalna $10000 \mathrm{obr} / \mathrm{min}$,

- bezwładność $0,368 \mathrm{~J} /\left(\mathrm{kg} \cdot \mathrm{m}^{2}\right)$.

Na rysunku 8 przedstawiono charakterystykę $P=f(\omega)$ użytego hamulca [9]. 


\subsection{Engine test bench brake}

The engine test bench was equipped with a Ralpha 240 electrorotary brake made by AVL [8]. Its specifications are as follows [9]:

a) Maximum power $-240 \mathrm{~kW}$.

b)Maximum torque $-600 \mathrm{~N} \cdot \mathrm{m}$.

c) Maximum speed $-10,000 \mathrm{rpm}$.

d)Inertia $-0.368 \mathrm{~J} /\left(\mathrm{kg} \cdot \mathrm{m}^{2}\right)$.

Figure 8 shows the brake's characteristic $P=f(\omega)$ [9].

\subsection{Vibrometric system for measuring vibrations}

The vibrations generated by the engine were measured by a scanning vibrometric system PSV made by Politec. The system includes:

a) A controller (OFV-5000).

b) A decoder module.

c) Vibrometric head (PSV400).

The vibration measurement parameters are shown in table 3 .

Table 3. Vibration measurement parameters

Tabela 3. Parametry pomiaru drgań

\begin{tabular}{|c|l|c|}
\hline No./Lp. & \multicolumn{1}{|c|}{ Parameter/Parametr } & Value/Wartość \\
\hline 1 & $\begin{array}{l}\text { Kind of measurement/ } \\
\text { Rodzaj pomiaru }\end{array}$ & $\begin{array}{c}\text { Speed vector/ } \\
\text { Wektor prędkości }\end{array}$ \\
\hline 2 & Averaging/Uśrednianie & Off/Wytaczone \\
\hline 3 & $\begin{array}{l}\text { Number of samples/ } \\
\text { Ilość próbek }\end{array}$ & 4096 \\
\hline 4 & $\begin{array}{l}\text { Sampling frequency/ } \\
\text { Częstotliwość próbkowania }\end{array}$ & $2048 \mathrm{~Hz}$ \\
\hline 5 & $\begin{array}{l}\text { Measurement duration/ } \\
\text { Czas pomiaru }\end{array}$ & $2 \mathrm{~s}$ \\
\hline 6 & Filter/Filtr & $+\mathrm{No} / \mathrm{brak}$ \\
\hline 7 & Directivity/Kierunkowość & $20 \mathrm{kHz}$ \\
\hline 8 & $\begin{array}{l}\text { Barrier frequency/ } \\
\text { Częstotliwość zaporowa }\end{array}$ & $640 \mu \mathrm{V} / \mathrm{m}$ \\
\hline 9 & $\begin{array}{l}\text { Vibration range/ } \\
\text { Zakres drgań }\end{array}$ & \\
\hline
\end{tabular}

Figure 9 shows the adopted diagnostic circuit.

One should mention that it was not necessary to use a reference channel with a trigger arm in the investigations. This means that garage diagnostics without additional specialist equipment will be possible.

\section{Digital processing of vibration signal}

\subsection{Operations on signal in time domain}

Without proper signal processing direct measurements do not yield explicit results. In addition, the proposed method requires multidimensional measurements, i.e. of a series of vibrations in the torque domain.

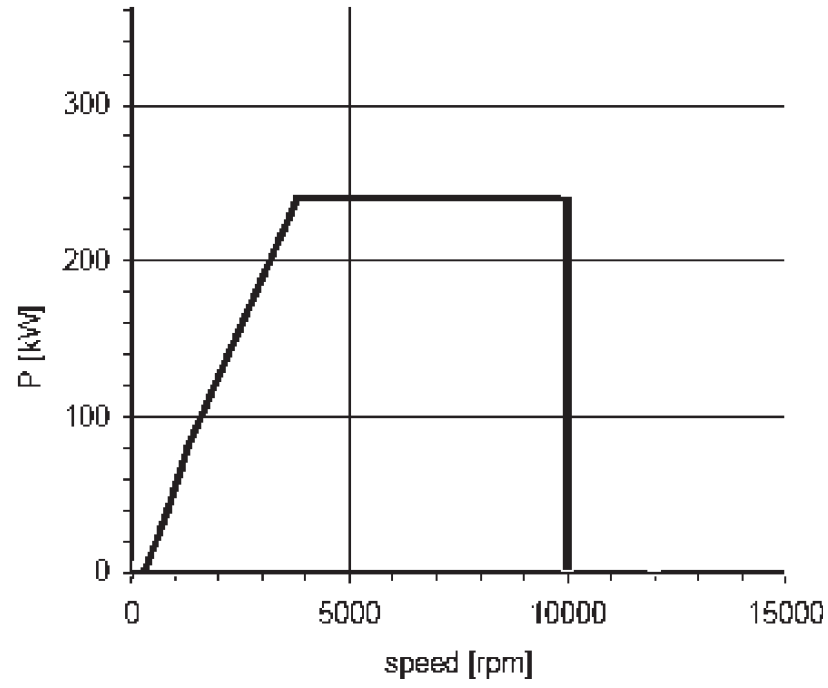

Fig. 8. Power characteristic of test brake

Rys. 8. Charakterystyka mocy hamulca użytego w badaniach

\subsection{Wibrometryczny system pomiaru drgań}

Do pomiarów drgań generowanych przez silnik użyto systemu wibrometrycznego, skanującego, firmy Politec, model PSV. W skład systemu wchodzi:

- kontroler (model OFV-5000),

- moduł dekoderów,

- głowica wibrometryczna (model PSV400).

Parametry pomiaru przedstawiono w tab. 3 .

$\mathrm{Na}$ rysunku 9 przedstawiono zastosowany tor diagnostyczny.

Należy nadmienić, że opisywane badania nie wymagały użycia kanału odniesienia z sygnałem wyzwalającym w układzie wibrometru. Pozwala to określać proponowana metodę jako łatwą w użyciu poza środowiskiem laboratoryjnym.

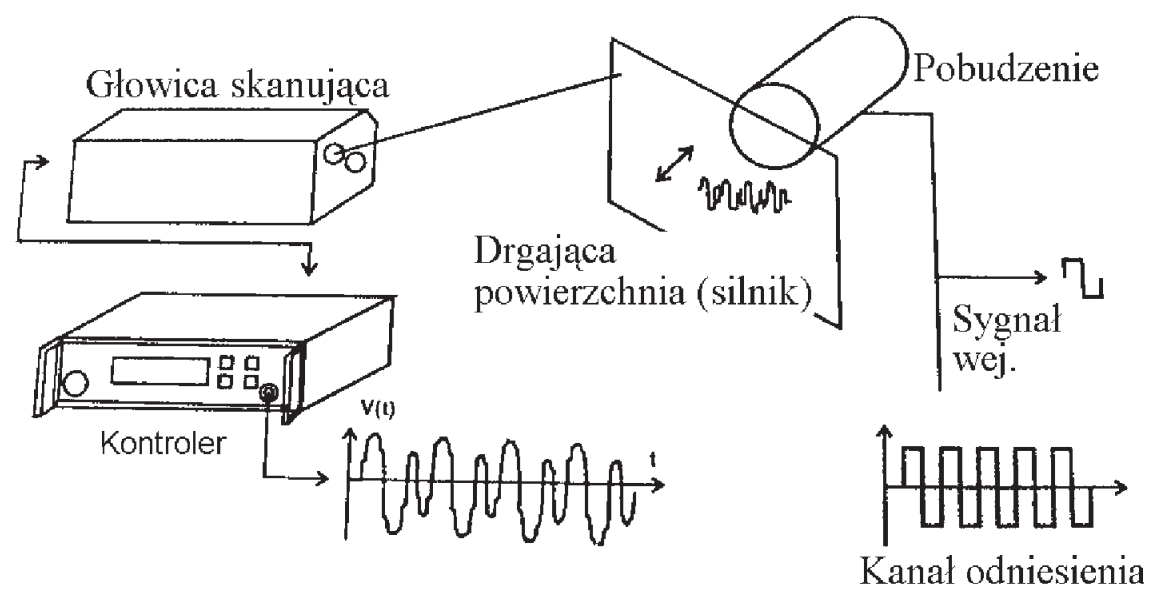

Fig. 9. Adopted diagnostic circuit Rys. 9. Zastosowany tor diagnostyczny 
The aim of all the signal digital processing operations performed during the investigations was to change the shape of the signal spectrum in a replicable way using standard methods. The first operation is signal windowing. In this case, windowing in the time domain since it is limited to the multiplication of the discrete vibration signal and the discrete window spectrum. Naturally, one could use a window in the frequency domain, but this would require the convolution of the two discrete signals.

A rectangular spectrum would have an ideal windowing sequence for damping uncharacteristic (from the investigation point of view) parts of the spectrum and simultaneously amplifying its characteristic parts. The ideal window would not distort the signal and prevent spectral leakage (an effect in which a part of the signal component, not situated by the frequencies for which the analysis is made, appears in all the output discrete signal values after transformation to the frequency domain [12]).

Since it is impossible to obtain a rectangular frequency characteristic a compromise is necessary. The compromise consists in the use of the best (from the investigation point of view) windowing sequence.

It has been experimentally found that a flap-top window is a good solution. This window is characterized by a low resolution at high dynamics [10]. Also its amplitude rendering accuracy is quite high. The values of this kind of window are calculated from the following formula (1) [10]:

$$
\begin{aligned}
\omega(\mathrm{t}) & =1-1,93 \cos \left(\frac{2 \pi \mathrm{t}}{\mathrm{T}}\right)+1,29 \cos \left(\frac{4 \pi \mathrm{t}}{\mathrm{T}}\right) \\
& -0,388 \cos \left(\frac{6 \pi \mathrm{t}}{\mathrm{T}}\right)+0,0322 \cos \left(\frac{8 \pi \mathrm{t}}{\mathrm{T}}\right)
\end{aligned}
$$

where: $0 \leq \mathrm{t} \leq \mathrm{T}$ and $\omega(\mathrm{t})=0$ for values from outside the domain.

Figure 10 shows the window's spectrum in the time and frequency domains.

\section{Cyfrowe przetwarzanie otrzymanego sygnału drgań}

\subsection{Operacje na sygnale w dziedzinie czasu}

Bezpośrednie pomiary bez właściwego przetwarzania sygnału nie pozwalają na otrzymanie jednoznacznych wyników. Opracowana metoda dodatkowo wymaga wykonania pomiaru, w wyniku którego otrzymano funkcje wielozmienną. Mowa tutaj o zastosowanej autorskiej metodyce pomiaru wartości prędkości względnej drgań w funkcji inkrementowanego momentu obrotowego.

Wszystkie operacje cyfrowego przetwarzania sygnałów użyte w badaniach mają na celu kondycjonowanie widma sygnału w sposób powtarzalny z użyciem znanych i wykorzystywanych metod. Pierwszą operacją jest okienkowanie sygnału. Operację tą wykonano w dziedzinie czasu, co pozwala na ograniczenie metody do operacji mnożenia dyskretnego sygnału drgań i dyskretnego widma okna. Oczywiście możliwe jest wykorzystanie okna w dziedzinie częstotliwości, ale wymagałoby to operacji splotu wymienionych sygnałów dyskretnych.

Idealny ciąg okienkujący powinien być dobrany tak, aby tłumić niecharakterystyczne (z punktu widzenia badań) części widma, przy jednoczesnym wzmocnieniu części charakterystycznych; idealne okno nie zniekształcałoby sygnału badanego i pozwalało na uniknięcie przecieku widmowego (zjawisko polegające na ujawnieniu się części składowej sygnału, nieleżącej przy częstotliwościach, dla których dokonujemy analizy, we wszystkich wyjściowych wartościach dyskretnych sygnału po transformacji do dziedziny częstotliwości [12]).

Uzyskanie prostokątnej charakterystyki częstotliwościowej okna jest niemożliwe; konieczny staje się kompromis, polegający na zastosowaniu najlepszego, z punktu widzenia badań, ciągu okienkującego.

Doświadczalnie stwierdzono, że dobrym rozwiązaniem jest okno typu „Flap Top”. Okno to charakteryzuje mała rozdzielczość przy dużej dynamice [10]. Ponadto charakteryzuje się znaczną dokładnością w odzwierciedlaniu amplitudy. Wartości dla tego rodzaju okna uzyskuje się z wzoru (2) [10],

gdzie: $0 \leq \mathrm{t} \leq \mathrm{T} \quad \mathrm{i}$ $\omega(\mathrm{t})=0$ dla wartości spoza dziedziny.

Widmo w dziedzinie czasu i częstotliwości użytego okna przedstawia rys. 10 .
Fig. 10. Flap-top window in time and frequency domains Rys. 10. Użyte okno typu „Flap Top” w dziedzinie czasu i częstotliwości 


\subsection{Transformation to frequency domain}

After windowing the signal is transformed to the frequency domain, using the fast Fourier transform with a base of 2. The way in which the FFT algorithm is introduced has been known since 1965 and it is widely described in the literature [10-12]. The fast Fourier transform used for discrete signals is expressed as follows:

$$
X(k)=\sum_{j=1}^{N} x(j) \omega_{N}^{(j-1)(k-1)}
$$

where: $\omega_{\mathrm{N}}=\exp \left(\frac{-2 \pi \mathrm{i}}{\mathrm{N}}\right) ; \mathrm{N}-$ the number of samples, $\mathrm{k}-$ the current sample of the frequency domain, $\mathrm{j}$ - the current sample of the time domain.

Thanks to the algorithm the calculations can be significantly speeded up and a modern PC does the job in a few seconds.

\subsection{Filtering in frequency domain. Remez algorithm}

One of the features of the discrete signal after the Fourier transformation, i.e. the time domain shift theorem, was used in the investigations. It follows from the definition of the Fourier transformation that a shift of the signal in the time domain by the value $\mathrm{x}$ is equivalent to multiplying the signal spectrum by the complex number $\mathrm{e}^{-\mathrm{j} \omega \mathrm{x}}[13]$. The multiplication result has no effect on the shift of the spectrum in the frequency domain. Generally, the dependence can be written as:

$$
\mathrm{x}\left(\mathrm{t}-\mathrm{t}_{0}\right) \stackrel{\text { FFT }}{\longrightarrow} \mathrm{X}(\omega) \mathrm{e}^{-\mathrm{j \omega t} \mathrm{t}_{0}}
$$

hence:

$$
\mathrm{x}\left(\mathrm{t}-\mathrm{t}_{01}\right) \stackrel{\text { FFT }}{\longleftrightarrow}|\mathrm{X}(\omega)|
$$

and

$$
\mathrm{x}\left(\mathrm{t}-\mathrm{t}_{02}\right) \stackrel{\text { FFT }}{\longleftrightarrow}|\mathrm{X}(\omega)|
$$

The above feature, thanks to which after the Fourier transformation (FFT) the spectral module is insensitive to time sample shift (5), (6), forms the basis of the proposed diagnostic method. There is no need to search for the same measuring point in each sample, i.e. for the top dead centre (TDC).

Since the spectral module is insensitive to the shift a decision was made to use the finite pulse response (FPR) filter design method. It is a very popular method of designing filters (except phase filters) [11].

In order to obtain the current output signal sample, FPR filters use only the previous samples and the current sample, which shortens and simplifies the analysis. As a result the method is suitable for real diagnostic systems.

The low-pass filter generated by the Remez method (also called the Parks-McClellan method) was amplified (Fig. 11).

Since the spectrum of the filter was characterized by considerable damping and low stability, the obtained filter samples were multiplied in the time domain by the Blackman window (7):

\subsection{Transformacja do dziedziny częstotliwości}

Po operacji okienkowania sygnał podlega transformacji do dziedziny częstotliwości przy zastosowaniu szybkiej transformaty Fouriera o podstawie 2. Wyprowadzenie algorytmu FFT jest znane od 1965 r. i szeroko opisywane w literaturze [10-12]. Wykorzystana postać szybkiej transformaty Fouriera dla sygnałów dyskretnych ma postać (3),

gdzie: $\omega_{\mathrm{N}}=\exp \left(\frac{-2 \pi \mathrm{i}}{\mathrm{N}}\right) ; \mathrm{N}-$ liczba próbek, $\mathrm{k}-$ bieżąca próbka dziedziny częstotliwości, $\mathrm{j}$ - bieżąca próbka dziedziny czasu.

Użyty algorytm pozwala na znaczne przyspieszenie obliczeń, a współczesny komputer pozwala na uzyskanie wyników w ciągu kilku sekund.

\subsection{Filtrowanie w dziedzinie częstotliwości. Algorytm Remeza}

W badaniach wykorzystano jedną z cech sygnału dyskretnego po transformacji Fouriera, a mianowicie twierdzenie o przesunięciu w dziedzinie czasu. $Z$ definicji transformacji Fouriera wiadomo, że przesunięcie sygnału w dziedzinie czasu o wartość $\mathrm{x}$ jest równoznaczne z pomnożeniem jego widma o wartość zespoloną $\mathrm{e}^{-\mathrm{j} \omega \mathrm{x}}[13]$. Wynik mnożenia nie ma wpływu na przesunięcie widma $\mathrm{w}$ dziedzinie częstotliwości. Ogólnie zależność tę możemy przedstawić w postaci (4), stąd (5) i (6).

Wymieniona właściwość, z której wprost wynika niewrażliwość modułu widmowego po wykonaniu transformaty Fouriera (w tym przypadku FFT) na przesunięcie próby czasowej (5), (6) leży u podstaw przedstawionej metody diagnostycznej. Nie ma konieczności szukania tego samego punktu pomiaru w każdej próbie, który musiałby polegać na szukaniu górnego martwego punktu (GMP).

Ponieważ moduł widma jest nieczuły na przesunięcie, zdecydowano się użyć metodę projektowania filtrów o skończonej odpowiedzi impulsowej (SOI), która nie pozwala na projektowanie filtrów fazowych. Mimo wszystko jest to bardzo popularna metoda projektowania filtrów [11].

Filtry SOI do uzyskania bieżącej próbki sygnału wyjściowego wykorzystują tylko próbki przeszłe i próbkę bieżącą. Skraca to i upraszcza analizę, co pozwala na wprowadzenie metody do rzeczywistych układów diagnostycznych.

Wygenerowany filtr dolnoprzepustowy metodą Remeza (zwaną także metodą Parksa-McClellana) został wzmocniony (rys. 11).

Ponieważ widmo uzyskanego filtru charakteryzowało się znacznym thumieniem i małą stabilnością, uzyskane próbki filtru zostały w dziedzinie czasu pomnożone z oknem Blackmana - wzór (7),

gdzie: $\mathrm{N}$ - liczba próbek, $\mathrm{k}$ - bieżąca próbka.

Tak uzyskany filtr przedstawiono na rys. 12 .

Tak przygotowane próbki filtru są wymnażane w dziedzinie czasu z próbkami widma częstotliwościowego drgań generowanych przez silnik. Należy tutaj zauważyć, że okienkowanie i filtrowanie są możliwe zarówno w dziedzinie czasu, jak i częstotliwości. Jednak okienkowanie w dziedzinie częstotliwości wymagałoby użycia operacji splotu widma częstotliwościowego okna i widma sygnału, zaś filtrowanie 


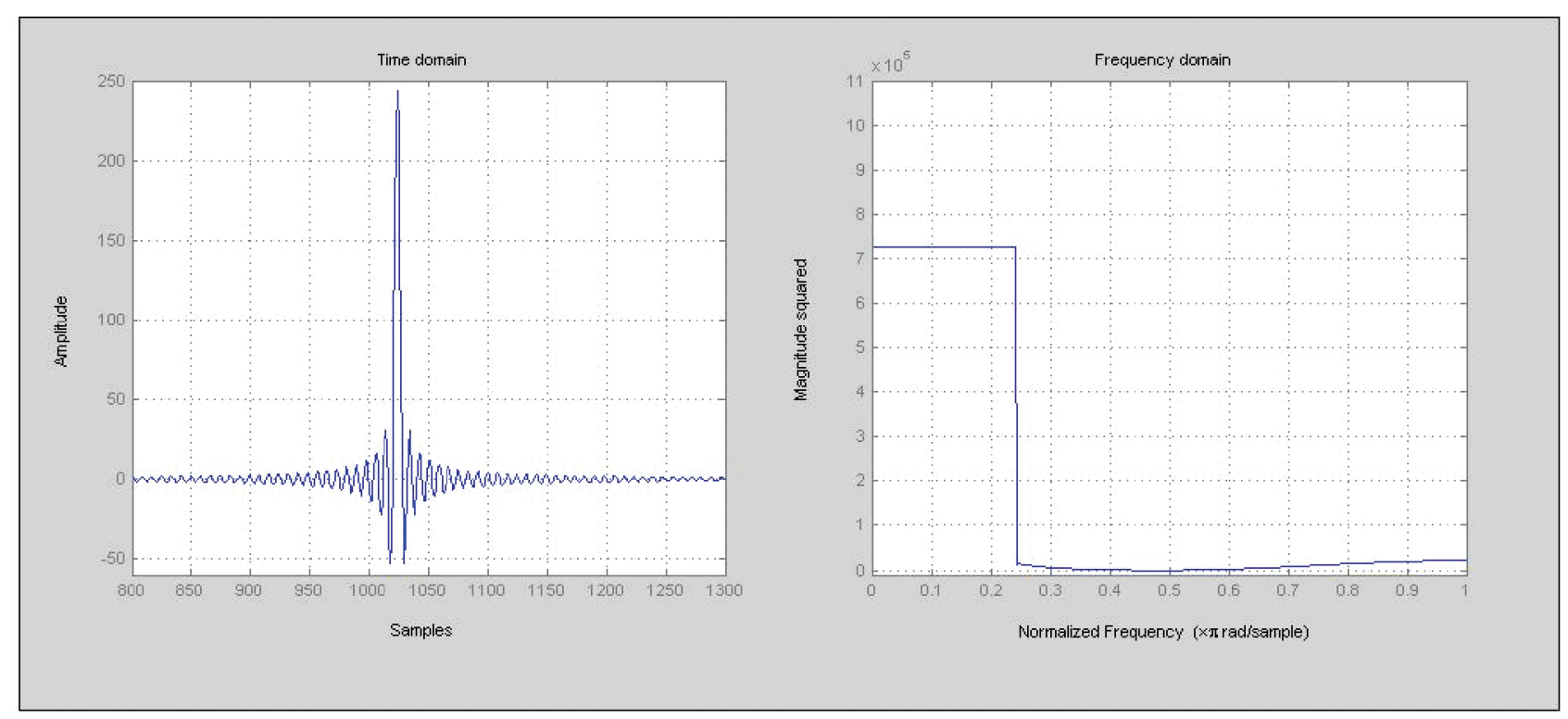

Fig. 11. Spectrum of FPR filter generated by Remez algorithm

Rys. 11. Widmo filtru SOI, wygenerowanego algorytmem Remeza

$$
\begin{aligned}
\omega(\mathrm{k}+1)= & 0,42-\cos \left(2 \pi \frac{\mathrm{k}}{\mathrm{N}-1}\right) \\
& +0,08 \cos \left(4 \pi \frac{\mathrm{k}}{\mathrm{N}-1}\right)
\end{aligned}
$$

where: $\mathrm{N}$ - the number of samples, $\mathrm{k}$ - the current sample.

The filter obtained in this way is shown in Fig. 12.

The filter samples prepared in this way are multiplied in the time domain by the samples of the frequency spectrum of the vibrations generated by the engine. One should note that windowing and filtering are possible in both the time domain and the frequency domain. However, windowing in the frequency domain would require the convolution of the window frequency spectrum and the signal spectrum and the filtering in the time domain would also require the convolution w dziedzinie czasu wymagałoby także użycia funkcji splotu widma czasowego filtru i widma sygnału drgań. Skomplikowałoby to metodę przez dodatkowe transformacje, a także konieczność używania splotu. Dlatego zdecydowano się na operację w dziedzinach „naturalnych” dla poszczególnych operacji, czyli mnożenie okna i sygnału w dziedzinie czasu oraz filtrowanie przez mnożenie próbek filtra i sygnału w dziedzinie częstotliwości. Bez względu na wybraną drogę, obie operacje są równoznaczne.

\section{Analiza wyników}

Opisane operacje cyfrowego przetwarzania sygnałów zostały wykonane wielowymiarowo. Oznacza to, że dla wszystkich sygnałów mierzonych przy różnych wartościach
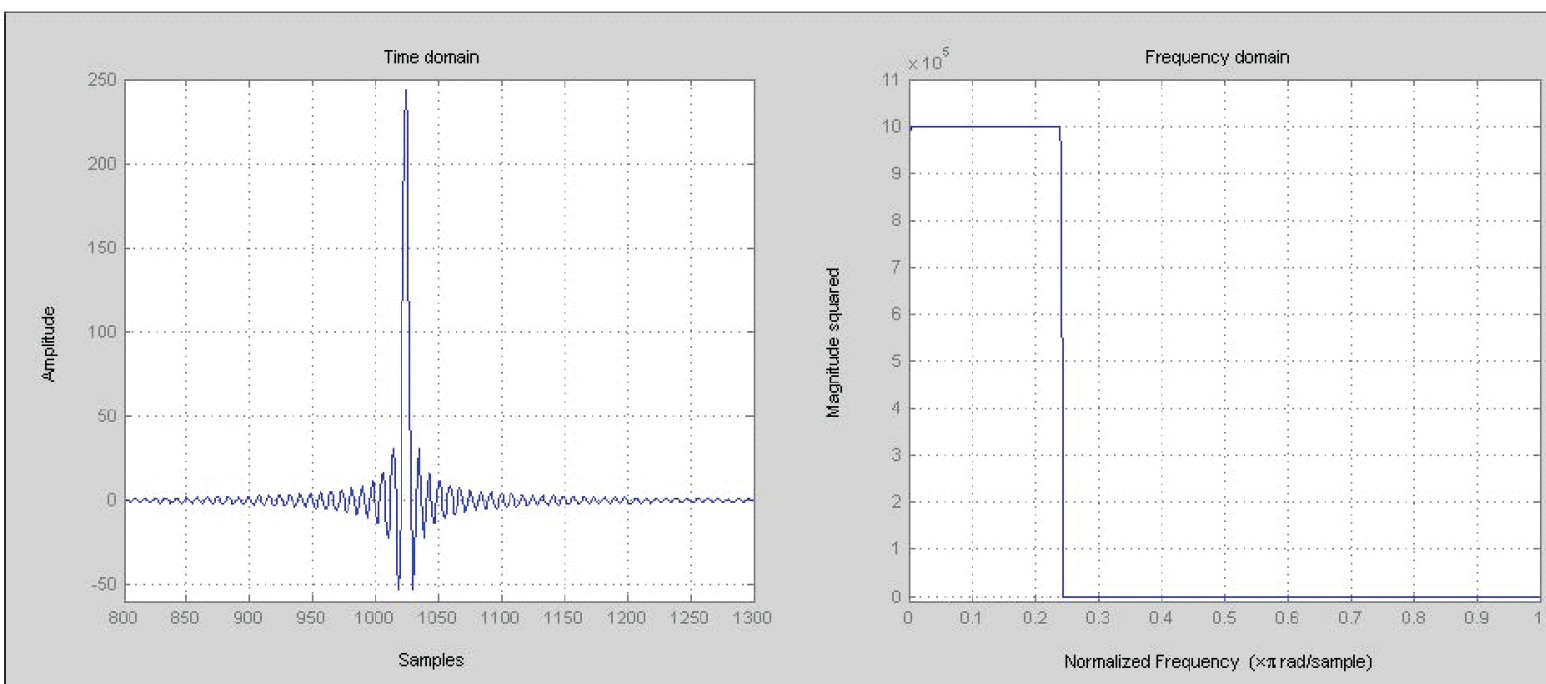

Fig. 12. Spectrum of FPR filter generated by Remez algorithm after windowing with Blackman window Rys. 12. Widmo filtru SOI, wygenerowanego algorytmem Remeza po zastosowaniu okienkowania oknem Blackmana 
of the filter time spectrum and the vibration signal spectrum. As a result of the additional transformations and the convolution, the method would become complicated. Therefore the particular operations were performed in their natural domains, i.e. windowing by multiplying the window and the signal in the time domain and filtering by multiplying the filter samples and the signal samples in the frequency domain. Regardless of the path taken, the two operations are equivalent.

\section{Analysis of results}

The digital signal processing operations were performed multidimensionally. This means that the digital signal processing operations described were performed for all the signals measured at different torques at a constant rotational speed.

In the first step, measurements were performed for the engine in good working order as the reference. The obtained characteristic is shown in Fig. 13. momentu obrotowego, przy stałej prędkości obrotowej należało wykonać opisane tutaj operacje cyfrowego przetwarzania sygnałów.

Pierwszy krok dotyczył pomiarów drgań silnika sprawnego, jako punktu odniesienia. Otrzymaną charakterystykę przedstawiono na rys. 13 .

Po wyłączeniu elektrozaworu układu EGR (rys. 3), wykonano kolejne pomiary drgań generowanych przez silnik. Otrzymany sygnał został przetworzony w sposób identyczny jak poprzednio. Uzyskany wynik przedstawiono na rys. 14. Zaznaczono obszar, w którym obserwuje się znaczne odchyłki amplitudy sygnału, jednoznacznie wskazujące na uszkodzenie układu EGR.

Zauważyć można, że funkcja dla momentu równego 30 i $40 \mathrm{~N} \cdot \mathrm{m}$ przedstawia odmienny charakter. Ponadto pomiar ten jest w pełni powtarzalny, ale charakterystyczny dla konkretnego silnika przy opisanej metodyce pomiaru. Zmiana w tym

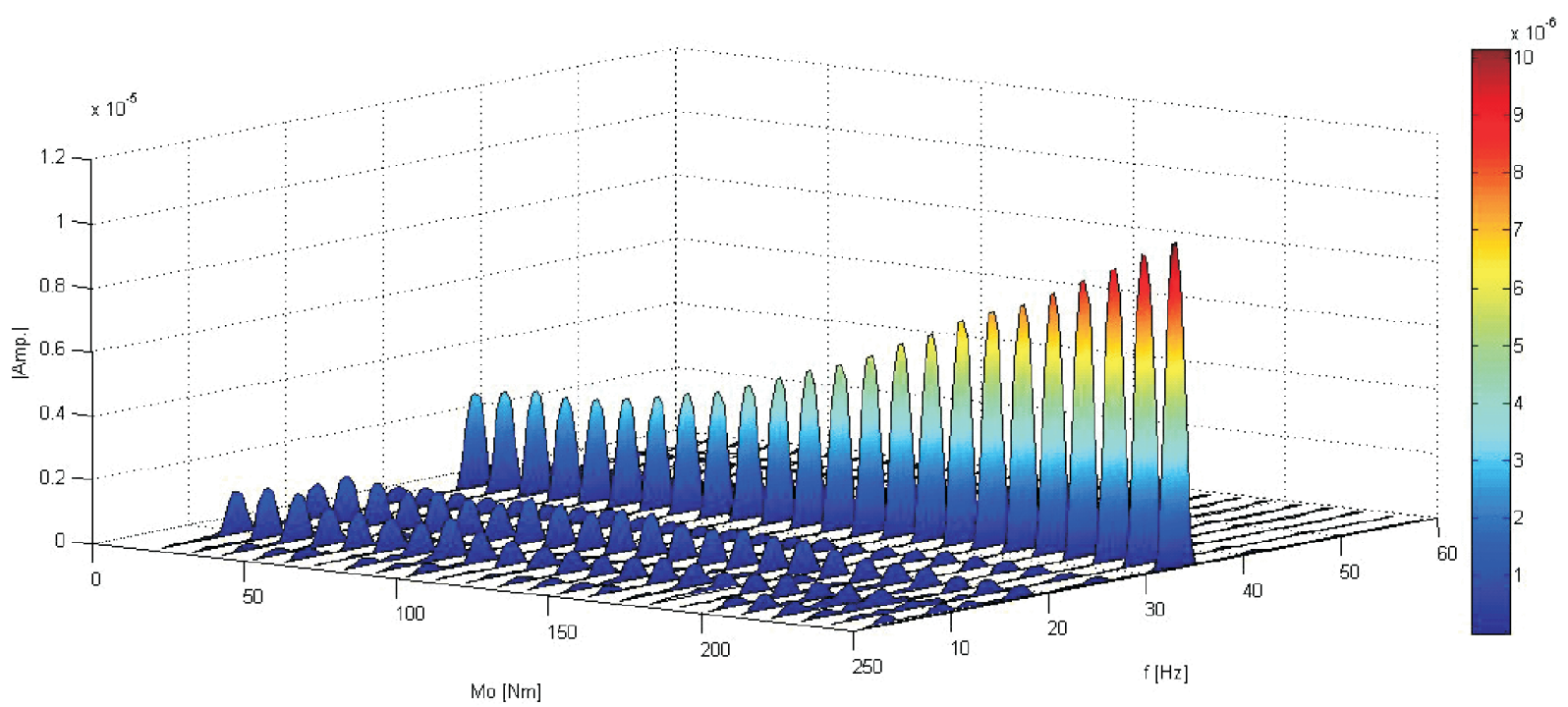

Fig. 13. Vibration versus torque spectrum of engine in good working order; $\omega=$ const

Rys. 13. Widmo drgań silnika sprawnego jako funkcję momentu obrotowego; $\omega=$ const

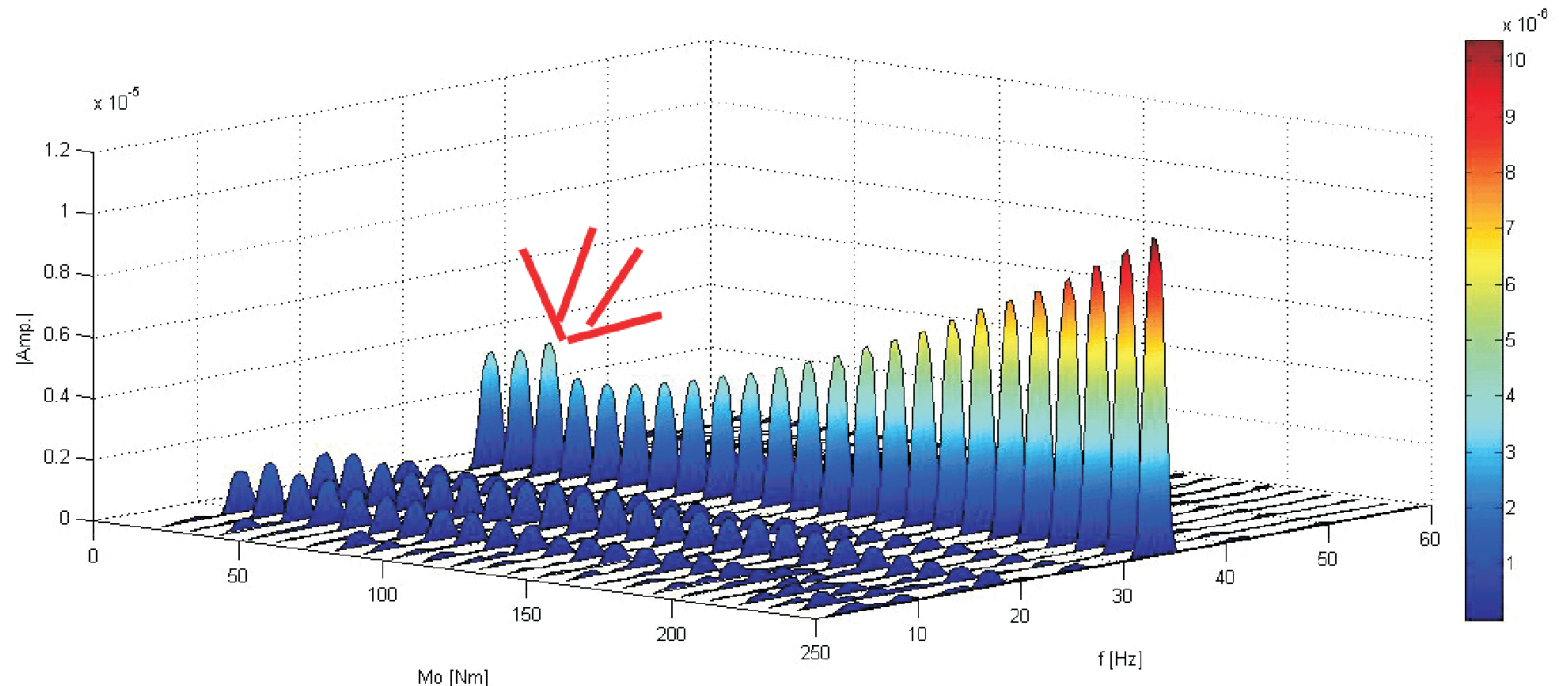

Fig. 14. Spectrum of vibration of engine with switched off EGR electrovalve versus torque; $\omega=$ const

Rys. 14. Widmo drgań silnika z uszkodzonym elektrozaworem systemu EGR jako funkcję momentu obrotowego; $\omega=$ const 
Then the EGR system electrovalve (Fig. 3) was switched off and the vibrations generated by the engine were measured again. The obtained signal was processed in the same way as previously. The result is shown in Fig. 14. The area in which considerable signal amplitude deviations are observed is circled.

One can notice that the function for the torque of 30 and $40 \mathrm{~N} \cdot \mathrm{m}$ has a different character. Moreover, the measurement is not fully replicable but characteristic for a given engine when the measurement methodology described here is used. The change here applies to a value of up to $-3.5 \mathrm{~dB}$.

\section{Conclusions}

1. Diagnostic of combustion engines without access to surfaces, based on the analysis of vibration, is possible. It is desirable to use a laser device for this purpose.

2. Although the method is quite complex, particularly in its digital signal processing aspect, it can be implemented in the widely available diagnostic systems thanks to the increasing popularity of signal processors.

3. Several faults and failures which until now have been considered to have a negligible effect or no effect on the operation of the engine can be immediately detected on the basis of engine vibrations.

4. The multidimensional analysis of engine vibrations allows one to predict failures. It apply to detect of EGR system defects which has affect to emission of combustion engines.

5. In the case of failures which clearly affect the vibrations generated by the engine, the one-dimensional function is sufficient for this type of diagnostics.

6 . The proposed method requires that measurements be performed for each model of the engine in good working order as the reference for further measurements. Measurements performed in accordance with the principles of digital processing of signals are replicable.

7. Engine vibrations are not an individual characteristic of each engine, but of the model.

Artykut recenzowany

Mr. Andrzej Kaźmierczak, DEng. - doctor in the Faculty of Mechanical Engineering, Wroclaw University of Technology.

Dr hab. inż. Andrzej Kaźmierczak - adiunkt habilitowany na Wydziale Mechanicznym Politechniki Wroclawskiej.

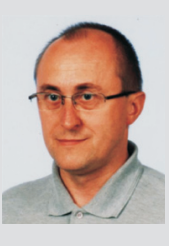

Mr. Radosław Wróbel, MEng. - PhD student in the Faculty of Mechanical Engineering, Wroclaw University of Technology.

Mgr inż. Radosław Wróbel - doktorant na Wydziale Mechanicznym Politechniki Wrocławskiej. przypadku dotyczy wartości sięgającej $-3,5 \mathrm{~dB}$.

\section{Wnioski}

1. Możliwa jest diagnostyka typu bezdotykowego silników spalinowych, oparta na analizie drgań. Pożądane w tym przypadku jest użycie urządzenia laserowego.

2.Prezentowana metoda, mimo znacznego stopnia skomplikowania, szczególnie w dziedzinie cyfrowego przetwarzania sygnałów, jest możliwa do wprowadzenia w ogólnodostępnych systemach diagnostycznych przez zastosowanie coraz bardziej popularnych procesorów sygnałowych.

3. Drgania silnika pozwalają wprost wykryć wiele uszkodzeń, w tym także takich, których wpływ na pracę silnika był uważany dotychczas jako niewielki, albo żaden. Dotyczy to także wykrywania uszkodzeń układu EGR, mającego wpływ na emisyjność silników spalinowych.

4. Możliwe jest przewidywanie wystąpienia uszkodzenia przez analizę drgań silnika $\mathrm{w}$ funkcji dodatkowych zmiennych, jak np. moment obrotowy.

5. W przypadku uszkodzeń, które w oczywisty sposób muszą mieć wpływ na drgania generowane przez silnik, do tego typu diagnostyki wystarczająca jest klasyczna funkcja jednowymiarowa amplitudy drgań w funkcji pulsacji dla stałej wartości momentu obrotowego i prędkości obrotowej wału korbowego.

6. Prezentowana metoda wymaga wykonania pomiarów dla każdego modelu silnika, działającego prawidłowo, jako punktu odniesienia do dalszych pomiarów, przy czym pomiary wykonane zgodnie $\mathrm{z}$ zasadami cyfrowego przetwarzania sygnałów są powtarzalne.

7. Drgania silnika nie są cechą indywidualną każdego silnika, lecz modelu.

\section{Bibliography/Literatura}

[1] en.wikipedia.org

[2] www.asashop.org

[3] forum.tdi-tuning.pl

[4] „Engine Technology International”, June 1999.

[5] Myszkowski S.: Instalator Polski: Diagnostyka Pokładowa.

[6] 60degreev6.com

[7] Merkisz J., Mazurek S.: Pokładowe systemy diagnostyczne pojazdów samochodowych, WKiÆ, Warszawa 2002.

[8] www.avl.com

[9] The Thrill of Solution: Dynamometers and Drivers. Wyd. AVL, update 12.04.2001.

[10] Stranneby D.: Cyfrowe przetwarzanie sygnałów. Metody, algorytmy, zastosowanie. Wydawnictwo BTC, Warszawa 2004.

[11] Zieliński T.P.: Cyfrowe przetwarzanie sygnałów. WKiÆ, Warszawa 2005.

[12] Lyons R.G.: Wprowadzenie do cyfrowego przetwarzania sygnałów. WKit, Warszawa 2006.

[13] Szabatin J.: Podstawy teorii sygnałów. WKiŁ, Warszawa 2003.

[14] skoda.autokacik.pl 